\title{
Lignocellulosic Waste Degradation Potential of Some Cellulolytic Fungal Strains Isolated from Putrid Fruits
}

\author{
H.A. Akinyele ${ }^{1 *}$ D, A.A.T. Taliat ${ }^{2}$ (D) G.C. Enwerem², O.G. Dawodu² and \\ O.S. Owojuyigbe ${ }^{2}$ if
}

${ }^{1}$ Federal University Oye-Ekiti, Ekiti State, Nigeria.

${ }^{2}$ Federal Polytechnic, Ede, Osun State, Nigeria

\begin{abstract}
Fungi are plentiful in nature and they are found growing on wastes of wood materials. These wastes are equally found in our environment with no usefulness. The aim of this study was to exploit the probability of the isolated fungi from fruits to produce cellulase from wastes of lignocellulosic materials. Cellulase- producing fungi were isolated from fruits (tomato, banana, plantain). The organisms were screened for cellulase production. Culture conditions were optimized with $\mathrm{pH}$, temperature and carbon. Cellulase was produced using lignocellulosic wastes; sawdust, corn cob, sugarcane bagasse. Six cellulase producers were isolated, four of which were selected for synthesis and quantification of the cellulase. The fungi were identified as Saccharomyces cerevisiae ${ }^{4}$, Trichoderma species $^{1}$ and Scopulariopsis brevicaulis ${ }^{1}$. Of all the tested substrates used in this study, pretreated sugarcane bagasse at $3 \% \mathrm{w} / \mathrm{v}$ concentration with Scopulariopsis brevicaulis gave highest cellulase production $18.18 \mathrm{U} / \mathrm{mL}$ at $40^{\circ} \mathrm{C}, 5$ day incubation time and $\mathrm{pH} 5$, followed by Trichoderma with $12.39 \mathrm{U} / \mathrm{mL}$. These fungi are good potentials cellulase producers that can be considered at industrial level.
\end{abstract}

Keywords: Fungi, peptone, substrate, plantain, cellulase

*Correspondence: hafiz.akinyele@fuoye.edu.ng

(Received: March 01, 2020; accepted: July 07, 2020)

Citation: Akinyele HA, Taliat AAT, Enwerem GC, Dawodu OG, Owojuyigbe OS. Lignocellulosic Waste Degradation Potential of Some Cellulolytic Fungal Strains Isolated from Putrid Fruits. .J Pure Appl Microbiol. 2020;14(3):2585-2593. doi: 10.22207/JPAM.14.4.34

(C) The Author(s) 2020. Open Access. This article is distributed under the terms of the Creative Commons Attribution 4.0 International License which permits unrestricted use, sharing, distribution, and reproduction in any medium, provided you give appropriate credit to the original author(s) and the source, provide a link to the Creative Commons license, and indicate if changes were made. 


\section{INTRODUCTION}

Cellulolytic enzymes are of three groups, Endo- $(1,4)-\beta$ - $D$ glucanase, Exo- $(1,4) \beta$ - $D$ glucanase and $\beta$ glycosidase (Zhang et al., 2006). Profitable productions of cellulase can be achieved through solid or submerged culture fermentation. Media used in cellulase fermentation may contain cellulose in different degree of limpidness or as raw plant waste substrate (Aiello, 1996). Enzymes including cellulases have been reported produced in a wide collection of organisms; fungi, bacteria and invertebrates (Gautam et al., 2010). Cellulases are of industrial importance specially used in the textile (Bhat, 2000), detergent ( (Karmakar and Ray, 2011), pulp and paper (Bedford et al., 2003), food (De Castro, 2008) waste treatment (Gupta et al., 2010), as well as improving digestibility of animal feeds ( Dhiman et al., 2002)

Cellulose is the most abundant and renewable biopolymer on earth. It is the dominating waste material from agriculture and constitutes the waste generated from both natural and manmade activities. Cellulose is generally degraded by a multi-complex enzyme called cellulases. Synergistic mechanism among three types of enzymes namely endoglucanase, exoglucanase and $\beta$-glucosidase are requisite for the inclusive enzymatic hydrolysis of cellulose biopolymer (Gao et al., 2008). Cellulose is a linear polymer of glucose and composed of anhydroglucose units attached together by $\beta-1,4$ glycosidic bonds. The number of glucose units in the cellulose molecules varies and degree of polymerization ranges from 250 to over 10,000 depending on the source and treatment method (Klemm et al., 2005).

Large quantities of lignocellulosic wastes are generated through forestry, agricultural practices and industrial processes, particularly from agro-allied industries such as breweries, paper-pulp, textile and timber industries. These wastes generally accumulate in the environment thereby causing pollution problem (Abu et al., 2000; Gilna and Khaleel, 2011). Lignocellulosic biomass is the most abundant organic material in nature with high biotechnological potential (Rastogi et al., 2010). The biological conversion of lignocellulosic materials into industrial products requires the use of cellulolytic and hemicellulolytic enzymes to release fermentable sugars, microorganisms play an important role in this (Jourdier et al.,
2012; Romano et al., 2013). Moreover, the plant biomass regarded as "wastes" can be recycled and transformed into valuable products such as biofuels, chemicals, cheap energy sources for fermentation, enhanced animal feeds and human nutrients (Howard et al., 2003). Microorganisms are the major sources of enzyme production industrially and the production of enzyme from microbes is highly treasured because of simplicity of cultivation, high yield and utilization of various cheapest sources (El-Shora et al., 2014b; Selvaraj and Arvind, 2015) and seasonal fluctuation of raw materials do not occur (El-Shora et al., 2014a),

Techniques are being used to reduce the wastes on the environment with the use of microorganisms to produce beneficial products to mankind (Lynd et al., 2002), hence this study was aimed to produce cellulase using cellulosic wastes with the fungi isolated from different fruits.

\section{MATERIALS AND METHODS Isolation procedure}

Ripe fruits (Tomatoes, Plantain, and Banana) were purchased at Timi Market, Ede, Osun State. The fruits were left on the laboratory bench for twenty-one days to allow for colonization by cellulase producing microorganisms. $5 \mathrm{~mm}$ cock borer was sterilized and used to remove tissue from area close to the edge colonization and attack of Spoiled Tomatoes, Plantains and Bananas to obtain actively growing mycelia. This was aseptically inoculated at the centre of sterile modified GPYA Media.(Glucose 4.0g, Peptone $0.5 \mathrm{~g}$,Yeast Extract $0.5 \mathrm{~g}$, Agar 1.5g, distilled water $100 \mathrm{mls}$, Chloramphenicol 0.05g). The plates were done in triplicate and incubated at $27 \pm 2^{\circ} \mathrm{C}$ for 5 days (Onilude, 1996; Osho, 2005). This procedure was carried out in air lamina flow chamber. The chemicals used were of analytical grade. Both the chemicals and Glassware were sterilized by autoclaving and hot air oven at temperature of $121^{\circ} \mathrm{C}$, for $15 \mathrm{~min}$ and $180^{\circ} \mathrm{C}$ for two hours respectively. Inoculating needles were sterilized by flaming.

Identification of pure fungal cultures of isolates

The isolated fungi were subcultured on sterile culture plates containing PDA medium to obtained pure culture of each isolate. Observation of microscopic characteristics of each isolate was done using sterile forceps to aseptically pick a 
strand of mycelium with the fruit body and it was carefully placed on a clean microscopic slide, stained with lactophenol blue and subsequently covered with a clean cover slip. Mycelium was then observed under the $x 40$ objective of the light microscope. Isolates were then subjected to both cultural and morphological characterization and compared with characteristics in the Fungal Compendium (Domsch et al., 1980). Each isolate was code labeled and sub-cultured regularly to maintain viability. Primary and secondary screening for cellulase production and activities were done according to methods described by Adesina and Onilude, (2013). The amount of reducing sugar present in the fermentation medium, cellulase activities were determined (Miller, 1959). This was done in conjunction with the method of Mandels and Webber (1969). One unit of cellulase was defined as the amount of enzyme that released I $\mu \mathrm{mol}$ reducing sugar as glucose equivalent per minute in the reaction mixture under the specified assay conditions. All enzyme assays were performed in triplicates.

\section{Cellulosic materials}

Sawdust of Iroko wood (Milicia excelsa) and Araba wood (Ceiba pentandra) were obtained at Oke Gada Sawmill, Ede, Osun State, Nigeria. Sugarcane bagasse and corn cob used in this study were obtained at Oje market of Ede, Osun State. Consequence of early $\mathrm{pH}$ on cellulase production

Ten milliliter $(10 \mathrm{~mL})$ each of sterile CPY broth (CMC $1.0 \mathrm{~g}$, Peptone $0.5 \mathrm{~g}$, Yeast Extract 0.5 $\mathrm{g}$,$) at \mathrm{pH} 5,6,7,8$ with $0.2 \mathrm{M}$ Phosphate buffer in sterile universal bottles were aseptically inoculated with $1 \mathrm{ml}$ inoculum of Trichoderma species, Scopulariopsis brevicaulis and Saccharomyces cerevisiae. Uninoculated sterile $\mathrm{CPY}$ at $\mathrm{pH}$ 5-8 in

Table 1. Consequence of diverse initial pHs on cellulase production

\begin{tabular}{ccccc}
\hline \multicolumn{5}{c}{ Isolates/cellulase activity } \\
\hline $\mathrm{pH}$ & $\begin{array}{c}\mathrm{TRC} / \\
\mathrm{U} / \mathrm{mL}\end{array}$ & $\begin{array}{l}\mathrm{SAC1} / \\
\mathrm{U} / \mathrm{mL}\end{array}$ & $\begin{array}{c}\mathrm{SAC3} / \\
\mathrm{U} / \mathrm{mL}\end{array}$ & $\begin{array}{c}\mathrm{SCB} / \\
\mathrm{U} / \mathrm{mL}\end{array}$ \\
\hline 5 & 2.45 & 2.45 & 2.56 & 2.67 \\
6 & 2.34 & 2.34 & 2.45 & 2.0 \\
7 & 2.22 & 4.11 & 2.34 & 1.67 \\
8 & 1.28 & 1.28 & 2.22 & 1.56 \\
\hline
\end{tabular}

universal bottles were used as control. The bottles were incubated at $27 \pm 2^{\circ} \mathrm{C}$ for 5 days.

\section{Cellulase assay at $\mathrm{pH} 5,6,7,8$}

Cellulase was assayed by centrifuging $5 \mathrm{mls}$ of the yeasts culture (broth) at 4000rpm for 30minutes while Trichoderma species and Scopulariopsis brevicaulis culture (broths) were filtered with Whatman No1 filter paper. $0.5 \mathrm{~mL}$ supernatant/filtrate of each culture was pipette into sterile test tubes containing $0.5 \mathrm{~mL}$ of sterile $0.5 \% \mathrm{CMC}$ at $\mathrm{pH} 7$ in $0.2 \mathrm{M}$ Citrate- phosphate buffer (Jeffries, 1996).The mixture was incubated at $50{ }^{\circ} \mathrm{C}$ for 30 minutes. $1 \mathrm{~mL}$ of DNSA Solution (Dinitrosalicylic acid) was added to the mixture and boiled in the water bath for 5 minutes. It was then allowed to cool in water for color stabilization before optical density was measured with spectrophotometer at 540nm (Acharya et al., 2008).

Consequence of diverse concentrations of carboxyl methylcellulose on cellulase production

The effect of different carboxyl methylcellulose concentrations from 0.5 \%-1.5\% was studied. $10 \mathrm{~mL}$ each of sterile modified CPY broth (CMC, Peptone, Yeast Extract) was inoculated with $1 \mathrm{~mL}$ inoculum of Saccharomyces cerevisiae, spores of Trichoderma species and Scopulariopsis brevicaulis culture aseptically. Uninoculated 0.5\%$1.5 \%$ sterile CPY broth in Marcatney bottles were used as control. The culture and control were incubated at $27 \pm 2^{\circ} \mathrm{C}$ for 5 days. Cellulase was assayed using method reported by Acharya et al. (2008).

Consequence of diverse temperatures on cellulase production by the isolates

Optimum temperature on cellulase production by the isolates was determined at temperature ranging from $30-50^{\circ} \mathrm{C}$. Cellulase was

Table 2. Consequence of varying temperatures on cellulase production

\begin{tabular}{lccccc}
\hline \multirow{2}{*}{ Isolates } & \multicolumn{5}{c}{ Temperature $(\mathrm{U} / \mathrm{mL})$} \\
\cline { 2 - 6 } & $30^{\circ} \mathrm{C}$ & $35^{\circ} \mathrm{C}$ & $40^{\circ} \mathrm{C}$ & $45^{\circ} \mathrm{C}$ & $50^{\circ} \mathrm{C}$ \\
\hline SAC1 & 3.0 & 5.01 & 5.56 & 7.01 & 5.45 \\
SAC3 & 2.89 & 2.57 & 3.22 & 5.56 & 4.34 \\
TRC & 1.11 & 1.67 & 2.67 & 3.57 & 1.67 \\
SCB & 1.22 & 2.22 & 5.56 & 2.89 & 2.89 \\
\hline
\end{tabular}


assayed using method reported by Acharya et al. (2008).

\section{Preparation of substrates}

The substrates were sundried, ground and sieved with a $2 \mathrm{~mm}$ mesh size (Irfan et al., 2011).

\section{Pretreatment of lignocellulosic substrates}

The substrates were alkali-treated by autoclaving the washed and dried lignocellulosic substrates at $121^{\circ} \mathrm{C}$ for $30 \mathrm{~min}$ with $0.25 \mathrm{M} \mathrm{NaOH}$ ( $20 \mathrm{~mL} / \mathrm{g}$ substrate). The substrates recovered by filtration through muslin cloth were thoroughly washed with de-ionised water and neutralized with $0.25 \mathrm{M} \mathrm{HCl}$. The substrates were finally washed with many changes of de-ionised water and dried at $65^{\circ} \mathrm{C}$ to constant weight (Singh et al., 1998)

\section{Fungal inocula preparation}

Sterilized molten CPY media (CMC 1.0 g, Peptone $0.5 \mathrm{~g}$, Yeast Extract $0.5 \mathrm{~g}$, Agar $1.2 \mathrm{~g}$, $100 \mathrm{~mL}$ distilled water) at $\mathrm{pH} 6$ was inoculated with yeast strains aseptically. Culture discs from Trichoderma species and Scopulariopsis brevicaulis culture plates cut separately with a cork borer (5mm diameter) were aseptically inoculated separately in $1 \%$ sterilized CPY media. After 5 days of growth at $27 \pm 2^{\circ} \mathrm{C}$ the cultures were used as inocula for cellulase production.

Outcome of varying concentrations of substrates on cellulase production

Preparation of media using treated and untreated cellulosic substrates

The substrates; soft wood sawdust from Araba wood (Ceibapen tandra), corn cob, sugarcane bagasse, hard wood sawdust from Iroko wood (Milicia excelsa) serving as carbon sources in the fermentation media were prepared by supplementing each substrates with Peptone and Yeast Extract. The media were prepared using appropriate buffers at $\mathrm{pH}$ 6. Each substrate was prepared in the range $1 \%-3 \% \mathrm{w} / \mathrm{v} .10 \mathrm{~mL}$ of each concentration was dispensed in sterile universal bottles, autoclaved at $121^{\circ} \mathrm{C}$ for 15 minutes, cooled and aseptically inoculated separately with $1 \mathrm{~mL}$ inocula of Saccharomyces cerevisiae, Trichoderma species and Scopulariopsis brevicaulis spores. Uninoculated sterile media at concentration $1 \%-3 \%$ were used as control. The bottles were incubated at $45^{\circ} \mathrm{C}$ for 5 days.

Cellulase assay by the isolates using lignocellulosic wastes

Cellulase was assayed by centrifuging $5 \mathrm{~mL}$ of the yeasts culture (broth) at 4000rpm for 30 minutes and filtered in the case of Trichoderma species and Scopulariopsis brevicaulis with Whatman No1 filter paper. $0.5 \mathrm{mls}$ supernatant/ filtrate of each culture was pipette into test tubes containing $0.5 \mathrm{mls}$ of Sterile $0.5 \% \mathrm{CMC}$ at $\mathrm{pH} 7$ with $0.2 \mathrm{M}$ Citrate-phosphate buffer (Jeffries, 1996). The mixture was incubated at $50^{\circ} \mathrm{C}$ for 30 minutes. $1 \mathrm{~mL}$ of DNSA (Dinitrosalicylic acid) solution was added to the mixture and boiled in the water bath for 5 minutes. It was cooled in water for color stabilization and the optical density was measured with a Spectrophometer at 540nm. (Acharya et al., 2008).

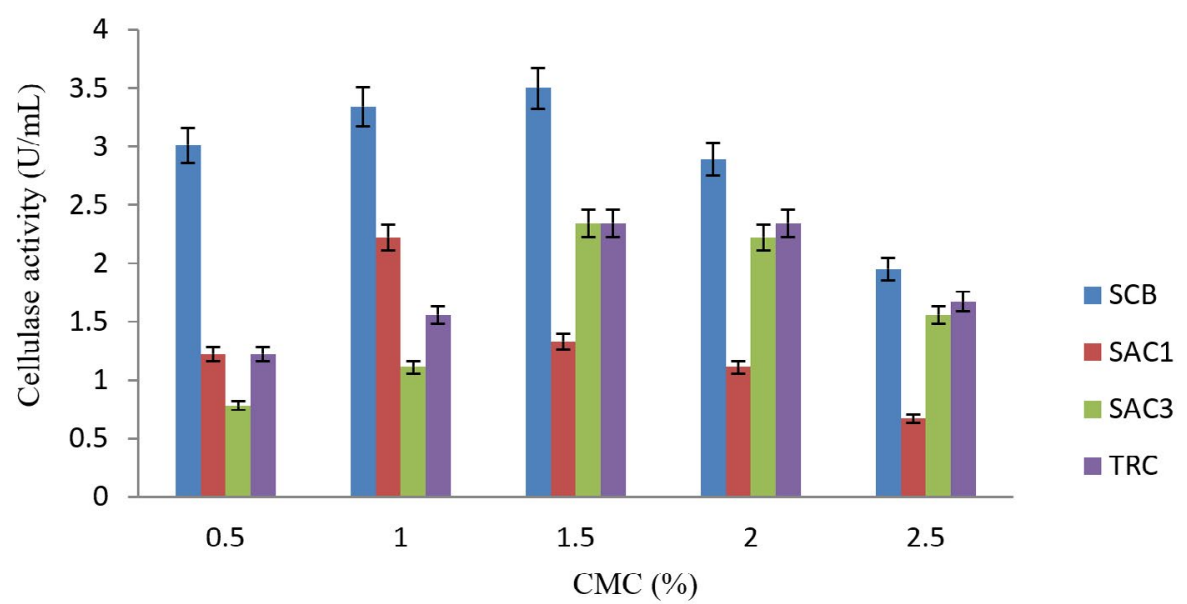

Fig. 1. Consequence of diverse concentrations of carboxylmethyl cellulose on the production of cellulanase by fungi isolates 


\section{RESULTS}

The six (6) fungi used in this study showed the ability to produce cellulase on carboxyl methyl cellulose. They include Saccharomyces cerevisiae (SAC1), Saccharomyces cerevisiae (SAC2), Saccharomyces cerevisiae (SAC3), Saccharomyces cerevisiae (SAC4) Trichoderma sp. (TRC) and Scopulariopsis brevicaulis (SCB) with relative enzyme activity $2.90,0.35,2.80,0.25,4.20$ and 4.02 respectively.

\section{DISCUSSION}

Various substrates such as pineapple pulp, paper, pineapple peel, sawdust, sugarcane

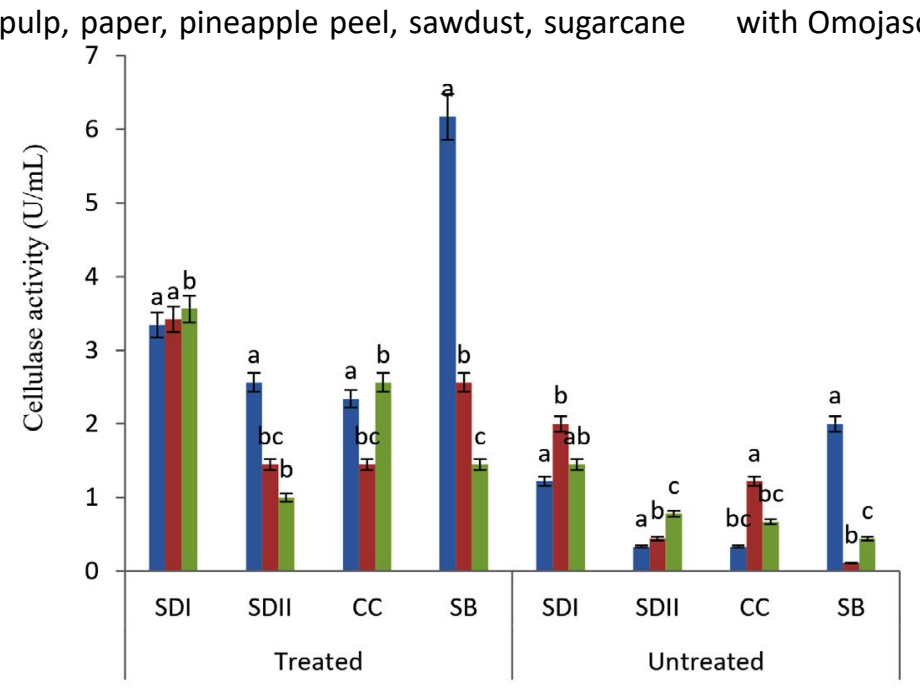

Fig. 2. Degradation ability of the isolates SAC1 on Lignocellulose Substrates

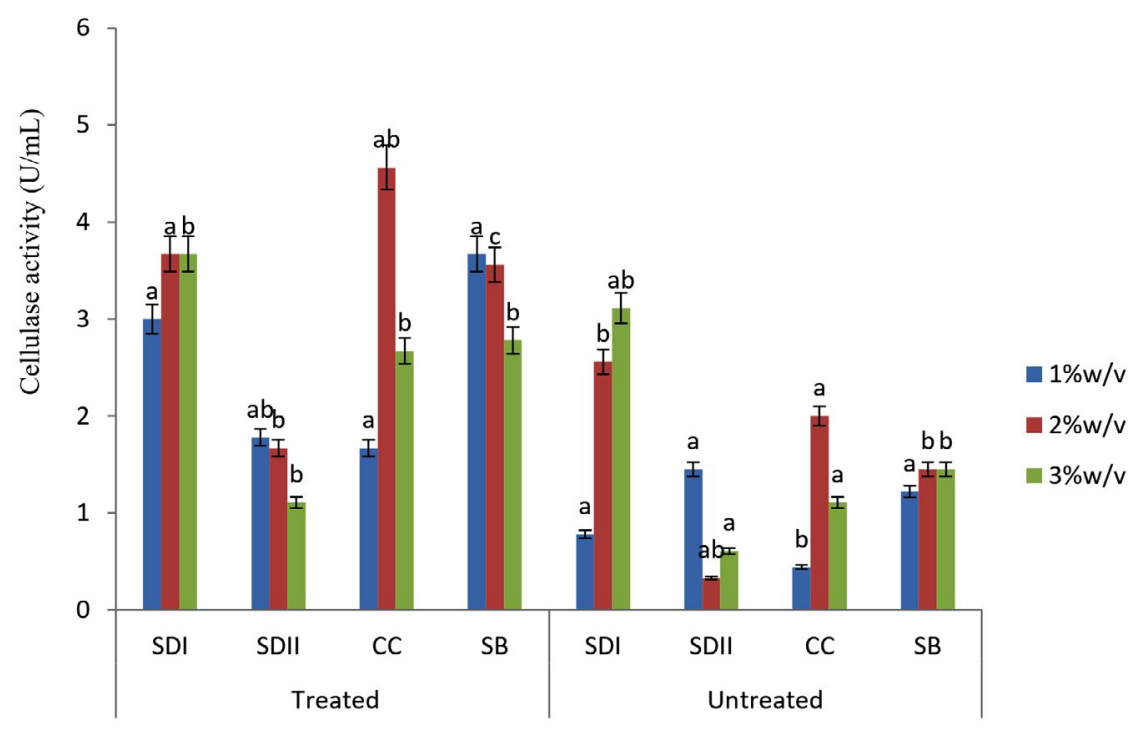

bagasse, wheat bran, beech wood have been used to produce cellulase. In this study, ability of cellulase produced by fungal isolates from fruits to degrade treated and untreated softwood sawdust from Araba (Ceibapen tandra), hardwood sawdust from Iroko wood (Milicia excelsa), corncob and sugarcane bagasse were studied. Parameters such as $\mathrm{pH}$, carbon source, temperature induce the yield of cellulase (Igbal et al., 2010). Maximum cellulase activity of $2.45 \mathrm{U} / \mathrm{mL}$ and $2.56 \mathrm{U} / \mathrm{mL}$ were noticed for TRC and SAC3 respectively at $\mathrm{pH}$ 5 while $4.11 \mathrm{U} / \mathrm{mL}$ cellulase activity was for SAC1 at $\mathrm{pH}$ 7. The result in this work is in conformity with Omojasola et al. (2008), who observed that 
$3.0 \mathrm{U} / \mathrm{mL}$ of cellulase was produced at $\mathrm{pH} 5$ by Saccharomyces cerevisiae. Selvaraj and Arvind, (2015) also reported higher cellulase production at acidic $\mathrm{pH}$. The high activity of the enzymes at acidic condition is an advantage for industrial fermentation.

Cellulase activity was greatly affected by the concentration of carbon source in submerged fermentation. The activity improved as the concentration of carboxyl methyl cellulose (carbon source) increased from $0.5 \%-1.5 \% \mathrm{w} / \mathrm{v}$ The maximum yield of cellulase by isolates SCB, SAC3 and TRC were $3.5 \mathrm{U} / \mathrm{mL}, 2.34 \mathrm{U} / \mathrm{mL}$ and $2.34 \mathrm{U} /$ $\mathrm{mL}$ respectively at $1.5 \% \mathrm{w} / \mathrm{v}$ concentration while it was $0.4 \mathrm{mg} / \mathrm{ml}$ for SAC1 at $1.0 \% \mathrm{w} / \mathrm{v}$.

The temperature at which enzymesubstrate reaction was incubated plays a significant role in cellulase productivity (Seyis and Aksoz, 2003). Cellulase action was investigated at different temperatures, from $30-50^{\circ} \mathrm{C}$. The maximum yield of cellulase by SAC1, SAC3 and TRC were $7.01 \mathrm{U} /$ $\mathrm{mL}, 5.56 \mathrm{U} / \mathrm{mL}, 3.67 \mathrm{U} / \mathrm{mL}$ respectively at $45^{\circ} \mathrm{C}$ while the minimum yield of cellulase were 3.0 $\mathrm{U} / \mathrm{mL}, 2.89 \mathrm{U} / \mathrm{mL}$ and $1.11 \mathrm{U} / \mathrm{mL}$ respectively at

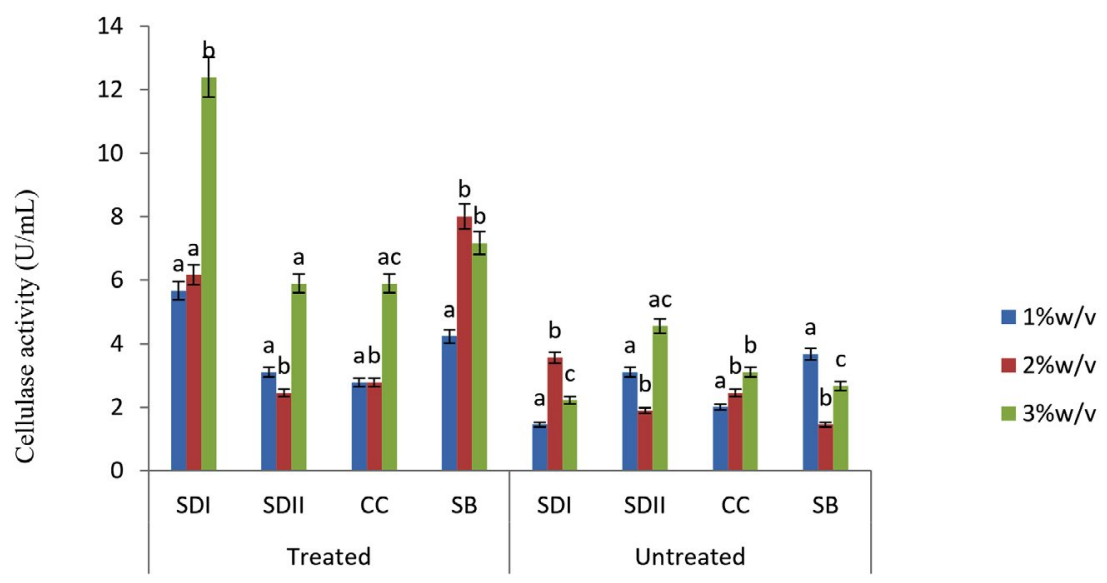

Fig. 4. Degradation ability of the isolates TRC on Lignocellulose Substrates

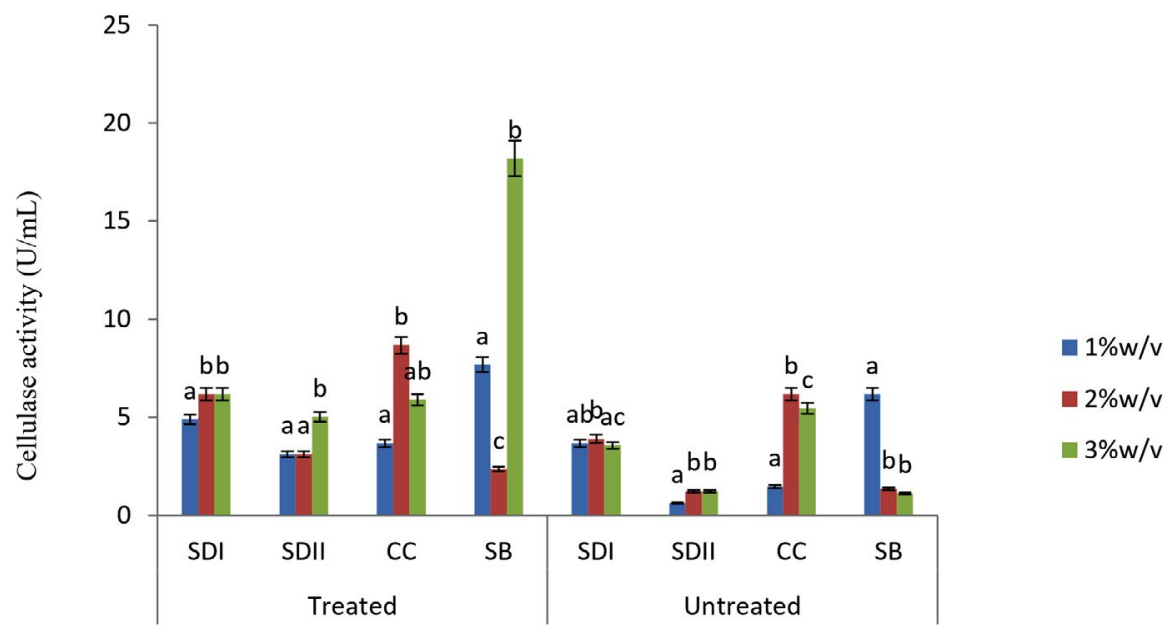

Fig. 5. Degradation ability of the isolates SCB on Lignocellulose Substrates

SDI Araba wood (Ceibapen tandra)-Sawdust, SDII Iroko wood (Milicia excels) -Sawdust: CC---Corn cob: SBSugar cane bagasse; Each value is a mean of two replicates; \pm stands for standard deviation among replicates; Means with different letters within each substrate differ significantly $(p \leq 0.05)$ using Duncan`s Multiple Range Test (Fig. 2, 3, 4 and 5) 
$30^{\circ} \mathrm{C}$ Fortkamp and Knop, (2014) observed that optimum enzyme production by most fungi is at mesophilic range. Increased temperature above $45^{\circ} \mathrm{C}$ lead to decreased in cellulase activity. This may be due to the fact that most of cellulaseproducing fungi are mesohpiles, though there are few thermophilic ones. Gautam et al. (2010) had earlier reported similar results.

In this study there were higher cellulase productions in treated soft wood Araba (Ceibapen tandra) than hardwood Iroko(Milicia excels) (Fig. 2-5). The fact that softwood has more cellulose than hardwood may be responsible for this. Cellulase activity for SAC3 increased from $1 \%$ $3 \% \mathrm{w} / \mathrm{v}$ concentrations of untreated softwood while the increment was up to $2 \% \mathrm{w} / \mathrm{v}$ for SAC1, TRC and SCB, after which a decrease in activity was noticed (Fig. 2-5). The maximum cellulase activities using treated and untreated softwood sawdust were $12.39 \mathrm{U} / \mathrm{mL}$ for treated and $3.89 \mathrm{U} /$ $\mathrm{mL}$ for untreated. The treated is isolates TRC and untreated for SCB (Fig. 4 and 5). The higher degree of fermentation of woody substrate in this study by Trichoderma sp. has earlier been reported. Adesina and Onilude 2013 observed that between $6.01 \mathrm{U} / \mathrm{mL}$ and $10.18 \mathrm{U} / \mathrm{mL}$ of glucanase activities were recorded for Trichoderma spp. isolated from wood chips. Maximum cellulase activities using treated hardwood sawdust were $5.01 \mathrm{U} /$ $\mathrm{mL}$ and $5.89 \mathrm{U} / \mathrm{mL}$ for SCB and TRC respectively at $3 \% \mathrm{w} / \mathrm{v}$. The activity is low when untreated hardwood was used. The variation in the amount of cellulase when treated and untreated hardwood was used may be due to the existence of some components (activators or inhibitors) in these materials (Mabrouk and Anwany, 2008). Result of cellulase production in different concentrations of treated and untreated lignocellulose showed that treated Sugarcane bagasse was more fermented by Scopulariopsis brevicaulis (SCB) with activity 18.18 $\mathrm{U} / \mathrm{mL}$ followed by $12.39 \mathrm{U} / \mathrm{mL}$ cellulase activity by isolate TRC in Ceibapen tandra at 3.0\% w/v (Fig. 4 and 5). Leghlimi et al. (2013) also reported the production of hydrolytic enzyme on lignocellulosic substrates by the organism. The higher amount of cellulase activity observed in the treated sugarcane bagasse than the other lignocellulosic materials had earlier been attributed to the increment in surface area and reduce crystallinity in sugarcane bagasse exposed to alkaline pretreatment (Akhtar et al. 2001). The general dissimilarity in the quantity of cellulase formed when treated and untreated lignocellulosic materials were used, especially the higher amount of enzyme produced with the treated is due to the removal of lignin. Lignin hinders the interaction of cellulase with cellulose locked up in lignocellulose ((Lynd et al., 2002; Ja'afaru and Fagade, 2007; Gautam et al., 2010).

\section{CONCLUSION}

Fungi are good sources of enzymes especially for industrial purpose. Temperature, $\mathrm{pH}$, nitrogen and carbon sources have substantial influence on cellulase production by the fungi investigated in this study. It was shown in this study that treated Ceiba pentandra and sugarcane bagasse gave maximum cellulase by Trichoderma $s p$. and Scopulariopsis brevicaulis respectively. These two fungi could be good sources of industrial cellulase.

\section{ACKNOWLEDGMENTS}

The authors are grateful for the financial support granted by the Federal Government of Nigeria under Tetfund Research Funding.

\section{CONFLICT OF INTEREST}

The authors declare that there is no conflict of interest.

\section{Authors' Contribution}

All authors listed have made a substantial, direct and intellectual contribution to the work, and approved it for publication.

\section{FUNDING}

Federal Government of Nigeria under Tetfund Research Funding Grant Number TETFUND/FPE/13/SLT/407

\section{ETHICS STATEMENT}

Not applicable.

\section{DATA AVAILABILITY}

All datasets generated or analyzed during this study are included in the manuscript.

\section{REFERENCES}

1. Abu EA, Onyenekwe PC, Ameh DA, Agbaji AS, 
Ado SA. Cellulase (E. C. 3. 2. 1. 3) production from sorghum bran by Aspergillus niger SL 1: An assessment of pretreatment methods. Proceedings of the International Conference on Biotechnology: Commercialization and Food security, Abuja, Nigeria. 2000:153-159.

2. Acharya PB, Acharya DK, Modi HA. Optimization of cellulase production by Aspergillus niger using saw dust as substrate. African Journal of Biotechnology. 2008;7(22):4147-4152.

3. Adesina FC, Onilude AA. Isolation, identification and screening of xylanase and glucanase-producing microfungi from degrading wood in Nigeria. African Journal of Agricultural Research. 2013;8(34):44144421. doi: 10.5897/AJAR2013.6993

4. Aiello C, Ferrer A, Ledesma A. Effect of alkaline treatment at various temperature on cellulase and biomass production of cellulase by Trichoderma reesei. Applied Microbiol Biotechnol. 1996;26:485-494.

5. Akhtar MS, Saleem M, Akhtar MW. "Saccharification of lignocellulosic materials by the cellulases of Bacillus subtilis," Int J Agr Biol. 2001;3:199-202.

6. Bedford MR, Morgan AJ, Fowler T, Clarkson KA, Ward MA Collier KD, Larenas EA. Enzyme feed additive and animal feed including it, US Pat 6562340 (to Genencore International Inc, USA). 2003.

7. Bhat MK. Cellulases and related enzymes in biotechnology. Biotechnology Advances, 2000; 18(5):335-383. doi: 10.1016/S0734-9750(00)00041-0

8. Dhiman TR, Zaman MS, Gimenez RR, Walters JL, Treacher R. Performance of dairy cow fed forage treated with fibrolytic enzymes prior to feeding. Animal Feed Science and Technology. 2002;101:(1-4): 115-125. doi: 10.1016/S0377-8401(02)00177-3

9. De castro IM, De Carvolho IM, Da Silva AB. "A study of retention of sugars in the process of clearing pine apple Juice by micro and ultra filtration". Journal of Food Engineering. 2008;87(4):447-454. doi: 10.1016/j. jfoodeng.2007.12.015

10. Domsch KH, Gams W, Anderson TH. Paecilomyces. In: Compendium of soil fungi. Academic Press, London. 1980;530-532.

11. El-Shora HM, Metwally AM, Mohammed RM, Sabry AS. Stability and immobilization of glucose oxidase from Cladosporium oxysporum. J Environ Sci. Mansoura Univ. Egypt. 2014a;43(2):253-266.

12. El-Shora HM, Salwa K, Zaki MO. Induction, purification, and biochemical characterization of cyanide hydratase from Cladosporiumoxysporum. The Ninth International Environmental Conference: Natural Resources and Sustainable Developments. 2014b;2014. Zagazig University

13. Fortkamp D, Knop A. High Xynlanase production by Trichodermaviride using pineapple peel as substrate and its application in pulp biobleaching. African Journal of Biotechnology. 2014:13(22);2248-2259. doi: 10.5897/AJB2013.13479

14. Gao J, Weng H, Zhu D, Yuan M, Guan F, Xi Y. Production and characterization of cellulolytic enzymes from the thermoacidophilic fungal Aspergillus terreus M11 under solid-state cultivation of corn stover. Bioresour Technol. 2008;99:7623-7629. doi: 10.1016/j. biortech.2008.02.005

15. Gautam SP, Budela PS, Pandey AK, Jamluddin AM, Sarsaiya S. Optimization of the medium for the production of cellulase by Trichoderma viride using smf. International Journal of Environmental Sciences. 2014;4(1):656-665.

16. Gilna VV, Khaleel KM.Cellulase enzyme activity of Aspergillus fumigates from mangroves oil on lignocellulosic substrates. Research in science and Technology. 2011;3(1):132-134.

17. Gupta R, Mehta G, Khasa YP, Kuhad RC. "Fungal delignification of lignocellulosic biomass in saccharification of cellulosic", Biodegration. 2010;22(4):797-804. doi: 10.1007/s10532-010-9404-6

18. Rathore HA, Nadeem TH, Ahmad A, Khaliq A. Effect of corn cobs concentration on xylanase biosynthesis by Aspergillus niger. African Journal of Biotechnology. 2012;11(7):1674-1682. doi: 10.5897/AJB11.1769

19. Howard RL, Abotsi E, Jansen van Rensburg EL, Howard S. Lignocellulose biotechnology: issues of bioconversion and enzyme production. Review. Afr J Biotechnol. 2003;2(12):602-619. doi: 10.5897/ AJB2003.000-1115

20. Igbal MN,Muhammad A,Ishtiaq A, Shahbaz H. Media optimization for hyper-production of carboxyl methylcellulose using proximally analyzed agro industrial residues with Trichoderma harzianum under solid state fermentation. International Journal for Medical Sciences. 2010;4(2):47-55.

21. Jaafaru MI, Fagade OE. Cellulase Production and Enzymatic Hydrolysis of Some Selected Local Lignocellulosic Substrates by a Strain of Aspergillus niger. Research Journal of Biological Sciences. 2007;2(1):13-16.

22. Jourdier E, Ben Chaabane F, Poughon L, Larroche C, Monot F. Simple kinetic model of cellulose production by Trichoderma reesei for productivity or yield maximization. Chemical Engineering Transactions. 2012;27:313-318.

23. Karmakar M, Ray RR. "Current trends in research and application of microbial cellulases", Research in Microbiology. 2011;6(1):41-53. doi: 10.3923/ jm.2011.41.53

24. Kiffer E, Morelet M. The Deuteromycetes. Mitosporic Fungi Classification and Generic Keys. U.S.A.: Science Publishers Inc. 2000;273.

25. Klemm D, Heublein B, Fink-habil HP and Bohn A. Cellulose: Fascinating Biopolymer and Sustainable Raw Material. Polymer Science, Angew. Chem. Int. Ed, 2005; 44, $3358-3393$

26. Leghlimi H, Meraihi Z, Boukhalfa-Lezzar H, Cappinet E, Duchiron F. Production and Characterisation of cellulolytic activities by Trichoderma longibrachiatum (GHL), Afr J Biotechnol. 2013;12(5):468-475. doi: 10.5897/AJB12.917

27. Lynd LR, Weimer PJ, van ZyI WH. Pretorius IS, Microbial cellulose utilization: Fundamentals and biotechnology. Microbiol Mole Biol Rev. 2002;66:506-512. doi: 10.1128/MMBR.66.3.506-577.2002

28. Mabrouk EM, Ahwany MD.Production of mannase by Bacillus amylolequifaciens cultured on potato peels. African Journal of Biotechnology. 2008;7(8):11-28. 
29. Mandels M, Weber J. The production of cellulases. $A d v$ Chem Ser. 1969;95:391-414. doi: 10.1021/ba-19690095.ch023

30. Miller GL. Use of dinitrosalicyclic reagent for the determination of reducing sugars. Analytical Chem. 1959;31:426-428. doi: 10.1021/ac60147a030

31. Omojasola PF, Jilani OP, Ibiyemi SA. Cellulase production by some fungi culture on pineapple wastes. Nature and science. 2008;6(2):64-79.

32. Onilude AA. Effect of cassavar cultivar, age and pretreatment processes of cellulase and xylanase production from cassava waste by Trichoderma harzianum. J Basic Microbiol. 1996;36:421-431. doi: $10.1002 /$ jobm.3620360607

33. Osho A. "Ethanol and sugar tolerance of wine yeast isolated from fermenting cashew apple juice. African Journal of Biotechnology. 2005;4:660-662. doi: 10.5897/AJB2005.000-3119

34. Rastogi G, Bhalla A, Adhikari A, Bischoff KM, Hughes SR, Christopher LP, Sani RK. Characterization of thermostable cellulases produced by Bacillus and Geobacillus strains. Bioresource Technology. 2010;101:8798-8806. doi: 10.1016/j. biortech.2010.06.001
35. Romano N, Gioffre A, Sede SM, Campos E, Cataldi A, Talia P. Characterization of cellulolytic activities of environmental bacterial consortia from an Argentinian native forest. Current Microbiology. 2013; 67:138-147. doi: 10.1007/s00284-013-0345-2

36. Selvaraj KRN, Arvind BRS. Evaluation of lignocellulosic agro wastes for the enhanced production of extracellular cellulase and xylanase by Trichoderma harzianum. Nature Environment and Pollution Technology. 2015;14(1):47-52

37. Seyis I, Aksoz N. Determination of some physiological factors affecting xylanase production from Trichoderma harzianum. 1073 D3. New Microbiol. 2003;26:75-81.

38. Shalini S, Sanamdeep S, Vrinda B, Lovleen S, Jyoti M. Production of Fungi Amylases Using Cheap, Readily Available Agriresidues for Potential Application in Textile Industry. BioMed Research International. 2014. doi: 10.1155/2014/215748

39. Singh A, Abidi AB, Darmwal NS, Agrawal AK. Evaluation of chemical pre-treatments for Biodegradation for Agricultural lignocellulosic wastes by Aspergillus niger. Mircen Journal. 1998;4:473-479. doi: 10.1007/ BF00940174

40. Zhang Percival YH, Himmel ME, Mielenz JR. “Outlook for cellulase improvement: Screening and selection strategies. Biotechnolgy Advances. 2006;24(5):452481. doi: 10.1016/j.biotechadv.2006.03.003 